\title{
TRAVERSES BETWEEN COGNITIVE CONSONANCE AND EXISTENTIAL CRISIS: NOTES ON JIANG MENGLIN'S PRAGMATIST NOTION OF RENSHENG GUAN AND HIS VIEWS ON SUICIDE FROM $1919^{1}$
}

\author{
JAN VRHOVSKI
}

\begin{abstract}
The article explores Jiang Menglin's philosophy of life and his notion of rensheng guan ("view on life") in the period between his studies in the USA and the year of the May Fourth events in 1919. In the first part, the paper traces the origins of Jiang's idea back to the then-prevalent version of pragmatism propagated by John Dewey and other pragmatist thinkers gathered at Columbia University, while in the subsequent parts it aims to illuminate the later developments of Jiang's own version of pragmatism in the context of the May Fourth intellectual discourse. While the article aims at presenting a positive outline of Jiang's philosophy, it also endeavours to expose its less explicit aspects through its apophatic (exposition by negation or denial) expositions in Jiang's writings from the period. Finally, it focuses on Jiang's contributions to the debate on suicide that developed after Lin Deyang's suicide in November 1919.
\end{abstract}

Keywords: rensheng guan; Jiang Menglin; pragmatism; May Fourth Movement; suicide

\section{Introduction}

By the mid-1920s the term rensheng guan 人生觀 (“view on life, life-view”) came to represent one of the defining ideas underpinning the major dilemmas of contemporary intellectual debates. Above all else, it designated the deepening ruptures between several philosophical currents and ideological options that dominated the Chinese intellectual landscape in the years immediately following the events of 1919. Although one could claim that the emerging divisions had already taken form over the seminal period of the radical transformation of the Chinese intellectual world at the beginning of the twentieth century, the influx of Western science and philosophies, which fundamentally marked the May Fourth period, provided Chinese intellectuals with new theoretical and conceptual means with which they could reassert their own internal differences and identities in light of new worldviews.

1 The author acknowledges financial support from the Slovenian Research Agency (ARRS) in the framework of research project N6-0161 (Complementary scheme) Humanism in Intercultural Perspective: Europe and China. I would also like to express my deepest gratitude to Professors Olga Lomová and Jana S. Rošker for their invaluable assistance in writing this essay. 
However, most importantly, the ebbs and flows in the Chinese intellectual world at this time represented a natural and inherently Chinese process, which encapsulated and entailed not only purely rational modes of appropriation and adaptation, but also a profoundly psychological process in which the transition from the constancy of the traditional order to the precarious abolitions of traditional social norms and moral inhibitions in Western scientific modernity incised deep cuts in the ideal worlds of Chinese intellectuals.

Among the emerging notions connected to the arising theoretical issues of the time was also the term rensheng guan. Although the term, designating "view on life" in the most general sense, had been used by scholars from the early twentieth century onwards, it acquired more specific connotations in the several years following the year of the May Fourth events (1919), until finally becoming a critical notion in the major intellectual debates of 1923 and 1924, one of chief manifestations of which was also the debate on “Science and the View on Life" (Kexue yu rensheng guan 科學與人生觀), also known as the debate on “Science and Metaphysics" (Kexue yu xuanxue 科學與玄學; see Zhang Junmai et al. 1997). At this later stage, the term rensheng guan was used to denote a broad philosophical view on life, which, in accordance with the standards of strict scientific objectivity, would eventually be branded a subjective abstraction of facts, intuitive insights into the general principles of life, non-objectivist ethics, and so forth. Or in the terminology of contemporary scientific realists and materialists: metaphysics. On the other hand, by the mid-1920s, the term rensheng guan, used by the proponents of the "philosophy of life," ${ }^{2}$ accumulated a variety of connotations, drawn generally from Western philosophical schools, which had in the preceding years gained prominence in China, most notably, pragmatism and vitalism. As strongly indicated by the name of the latter, the vocabulary utilized in the theoretical expositions of these two schools depended heavily on notions of life and its evolution.

In 1919, when this term first began to be used with greater frequency in Chinese written discussions, its later set of connotations were still not closely linked together as they would be in the years to come. As I will try to show in this essay, an important conceptual source for the later understanding of the term view on life was American pragmatism, which at the time was propagated by philosophers at the prestigious National Peking University. Here, I shall focus on the early work of the renowned educator Jiang Menglin 蔣萝麟 (1886-1964), who, along with the philosopher Hu Shi 胡適 (1891-1962), played

\footnotetext{
However, the evolution of such a "philosophy of life", which came to life in the process of the Sinicization of the Western philosophical current of vitalism, cannot be confused with the genuinely Chinese "philosophy of life" (shengming zhexue 生命哲學) developed by several proponents of the neo-conservative revival of Chinese ideational tradition, for instance, Fang Dongmei 方東美 (1899-1977). This stream of the Chinese philosophy of life cannot be confused with the philosophical movement that spread in Germany in the late nineteenth and the early twentieth centuries known as Lebensphilsophie (also referred to as German vitalist philosophy), even though the two discourses share some commonalities, such as a critique of purely materialist and mechanistic approaches to human existence and thought. These two philosophical discourses also proceeded from similar lines of thought in their basic epistemology, for both were rooted in the supposition that a comprehension of life can only be obtained by and through life itself, and from within itself. In the European philosophy of life, these epistemological bases were mainly established upon the foundation of the ideas of Schopenhauer, Kierkegaard, and Nietzsche, while in Chinese philosophical vitalism these basic notions go as far back as to the oldest written sources of the Chinese tradition, e.g., to the Book of Change (see Rošker 2021, 66).
} 
a key part in disseminating American pragmatism in late-1910s and 1920s China. In the following discussion I will first try to cast some light on Jiang's original conception of philosophy of life and the related notion of "view on life" during his studies at Columbia University in New York, which were epitomized in his doctoral dissertation entitled "A Study in Chinese Principles of Education". In doing so, I shall also reflect on the pragmatist origins of Jiang's views on life and education. Second, this study will provide a closer look at the development and expression of Jiang's view on life in the later Chinese period of his intellectual path, focusing on the year of the May Fourth events, 1919. In this context, in the last, central part of this paper I will discuss Jiang's contribution to the 1919 debate on suicide, casting some light on his notion of life through a negative, apophatic perspective.

\section{Jiang Menglin and Pragmatism}

Born in 1886, Jiang belonged to the generation of young intellectuals who grew up under the formative influence of the pioneers of Chinese modernization and disseminating Western science and political and philosophical thought in China. Jiang's profound interest in "things Western" was thus kindled by the writings of figures such as Liang Qichao 梁啓超, and his understanding of Western civilization was developed through reading periodicals such as the New Citizen (Xinmin congbao 新民叢報), founded by Liang in 1902 (Jiang 2004, 69-70). Jiang's interest in Western science and his propensity to engage in a Chinese search for a bright new tomorrow, which was sparked by the reform movement, caused Jiang to seek a Western education. Consequently, after completing his studies at Zhejiang Advanced College (Zhejiang gaodeng xuetang 浙江 高等學堂) in 1908, Jiang enrolled at University of California, Berkley. ${ }^{3}$ As a freshman at Berkeley, Jiang initially pursued a major in agriculture. According to his memoirs, he chose this field out of a sense of duty to contribute to strengthening the Chinese economy, which, he believed, depended on a strong domestic agricultural sector (ibid., 99). Only six months later, Jiang decided to change his major to pedagogy. This time, Jiang's decision was motivated by one of his friends, who persuaded him to drop agriculture for the social sciences. Eventually, Jiang chose pedagogy after he realized that studying how to foster talent might be more important than studying how to cultivate plants (ibid., 101). In the remaining years of his undergraduate studies, in addition to a major in pedagogy, Jiang also read history and philosophy, which enabled him to become more familiar with the prevailing trends in American philosophy. Thus, it was only a matter of time before Jiang was drawn to a philosophy that integrated all key concepts in his academic interests, from the notion of life to pedagogy. This fashionable and progressive American philosophy of the period was pragmatism, the academic centre of which was at Columbia University in New York. Apart from its comprehensive view, which stringed together the pillars of humanism and philosophy, pragmatism also contained another quintessential feature that attracted Jiang's attention: the proximity of its cosmological view to traditional Chinese thought - while the reverse could have been true for West-

Jiang's decision to continue his undergraduate studies in the USA was also influenced by his visit to Japan in 1907 (Jiang 2004, 90-91). 
ern philosophy related to the physical sciences. It was probably pragmatism's seemingly human life-centred notion of objectiveness, especially in the work of John Dewey, that convinced Jiang of this philosophy's highest relevance for both his education in the West and his future work in China; throughout his studies in the USA, Jiang always sought to link Western thought to Chinese thought (see ibid., 102-3). Another important aspect of Dewey's pragmatism, which was highly relevant for the contemporary Chinese intellectual climate, was his non-dualistic approach towards human nature and experience, built on his interpretation of Darwinian evolution (see Wang 2019, 17-19). ${ }^{4}$

Motivated by his newly awakened interest in pragmatism, following his graduation from Berkeley in 1912, Jiang decided to continue his graduate studies at Columbia University (ibid., 121-3). At Columbia, the heart of the American pragmatist movement, Jiang's initially narrow idea of the pragmatist philosophy of education started to mature into a more comprehensive worldview. Under the guidance of Dewey, the latter's pupil and colleague, the pedagogue William H. Kilpatrick (1871-1965), and others, an important part of his formative experience at Columbia was epitomized in his doctoral dissertation, "A Study in Chinese Principles of Education," which he submitted in June 1917. This document does not merely reveal the manner and extent of Jiang's appropriation of pragmatist ideas; more importantly, it provides testimony of Jiang's effort to gain an objective, new, and above all potentially beneficial and practically applicable understanding of the Chinese intellectual past and its role in a modernized Chinese society. In contrast with $\mathrm{Hu}$ Shi's dissertation, which was, at least nominally, devoted to the modern (pragmatist) rediscovery of ancient Chinese logical thought, Jiang's work aimed to reveal the historical roots of "Chinese principles of education" and "Chinese ideals of life" as well as potential solutions to the inherited limitations of their contemporary version. Jiang also reserved some place for a discussion of what later became known as "the Needham Question", that is, the question of "why China has not developed modern science" (Jiang 1918a, ii), which was followed by an extensive comparison of modern Western and Chinese ideas about society. In this study we shall take a closer look at the notion of life in Jiang's dissertation.

\section{Forming a Pragmatist View on Life: Jiang's Dissertation}

As a student of the pragmatist philosophy of education at Columbia, Jiang deeply immersed himself in the pragmatist worldview. Between 1912 and 1917, Jiang witnessed the key moments in the formation of Deweyan pragmatism. While Jiang was at Columbia, Dewey's works, such as Moral Principles of Education (1909), The Influence of Darwin

4 First, in the above statement the expression "non-dualistic" refers to the idea of "dualism" as a contradictory opposition of binary categories, concepts, principles, and so on, whereas its reverse, "non-dualism", implies a complementarity or continuity between entities, which in that case one still recognizes as diverse in nature and substance. Put into an epistemological perspective, such "non-dualism" would imply a continuum between objective and subjective experience, between the totality and the individual. It is at this point that I tentatively draw the connection between Dewey's cosmology/epistemology and traditional Chinese thought. Second, the cosmological implications of the Darwinian theory of evolution were highly in vogue in the late-nineteenth-century and early-twentieth-century Chinese intellectual discourse (see Furth 2002, 19, 26, 28, 51). 
on Philosophy (1910), How We Think (1910), and his writings on logic (1910) and epistemology, were still at the forefront of pragmatism at the university, but when it came to Jiang's ideas probably the most influential was Dewey's Democracy and Education: An Introduction to the Philosophy of Education, which was completed in 1915 and first published in 1916.

Generally speaking, Dewey's philosophical outlook was rooted deeply in the pragmatist notion of life as the fundamental epistemological and ontological category. In this regard, the epistemological premise stipulated that the value of knowledge and cognition is determined by its practical utility and effectiveness both in the short-term perspective of a singular human life as well as human evolution in the long term. On the other hand, apart from the idea of a constantly changing universe, the main ontological category of pragmatism was biological existence as such. In this context, human knowledge, logic, education, and ethics all served a single purpose: the development, enrichment, and preservation of human life. The pragmatist worldview was profoundly linked to contemporary philosophical and social interpretations of the Darwinian theory of evolution, which was very probably the main source for this philosophy's conceptions of "usefulness" and "effectiveness". Most importantly, pragmatists like Dewey maintained that rational utilities such as logic and knowledge, the final product of human cognition, ought to be regularly realigned with the perpetually changing physical reality, which, in the ontological sense, embodies the main conditions of preserving and enriching life as such. This is the principal basis of Dewey's concept of "experimentalism" as the main methodological principle of the pragmatist worldview. ${ }^{5}$

With regard to education, the above views were epitomized in Dewey's Democracy and Education, which, as its content reveals, served as an important source for Jiang's dissertation. The main arguments of Jiang's dissertation not only were built on the idea of "education as a necessity of life", expounded in the first chapter of Dewey's book, but also completely adopted the principles and aims of education as outlined in the mentioned work. As mentioned above, Dewey regarded education as an important means of human survival and the key conduit for transmitting human experience, for the "renewal of life by transmittance" (Dewey 1916a, 1-5). On the other hand, the guiding principles of education as imagined by Dewey consisted of scientific naturalism, humanism based on individualism, and, as revealed by the title of the book, democracy.

Drawing from Dewey's views on life and education, Jiang endeavoured to put the evolutionary dimensions of Dewey's theory into the context of China, its historical experience, and contemporary problematics - as seen from a, so to say, "modernist" perspective. This urge to establish a broader historical context originated in pragmatism's rootedness in a variety of natural evolutionism, while, at the same time, it was also an important ingredient in the premises of most modernist objectivisms. On the other hand, the necessity to regard Chinese histories (of education, philosophy, etc.) as descriptions of particular strains within the general current of human intellectual evolution also entailed a certain degree of cultural relativism, a notion which at that time was still in its earliest

For the textual source of the views summarized in this paragraph, see, e.g., Dewey 1916b, 1-2, 10, 12-13. 
stage of formation at Columbia as well as in the Chinese intellectual world. ${ }^{6}$ However, akin to his colleague and the other Chinese doctoral student of Dewey's, Hu Shi, in his dissertation Jiang seems to have completely adopted the pragmatist perspective. Whereas $\mathrm{Hu}$ Shi in his dissertation "An Outline of Logical Method in Ancient China" (1917) set out to locate proto-pragmatist ideas in traditional Chinese logic, Jiang used pragmatist ideas not only as a background for his evaluation of the, as it were, "evolutionary" inadequacies of Chinese culture and its system of education but, above all, as the foundation for their modern reformation.

Akin to $\mathrm{Hu}$ Shi, Jiang also proposed his own vision of Chinese intellectual history, which served as the foundation upon which he reconstructed the main characteristics of the notion of life in Chinese society and its basic requirements with regard to education. Jiang's study rested heavily on the pragmatist notion of life. Already in the opening lines of the first chapter of his dissertation, Jiang pointed out one of the main premises of his treatise: "One of the most fundamental ideas of the life of the Chinese is duty. To live is to fulfil the duties of life" (Jiang 1918a, 1). In Jiang's view, this notion of life was intricately linked to the Chinese system of education because "education is the method of life and thought, and life and thought are the contents of education" (ibid.). In the light of this notion of life, Jiang's subsequent revision of Chinese intellectual history revolved mainly around Confucianism as the main source of the idea of duty, which underpinned Chinese notions of the individual and society. Because, according to Jiang, in Confucianism the "fulfilment of duty" was seen as "the only way to happiness", the Chinese idea of life was "socialistic rather than individualistic" (ibid., 2). In the context of this "socialistic" turn in the Confucian notion of life, institutions became "the [principle] expressions of life" (ibid., 3), while the "peace and wellbeing of people" fell into the exclusive domain of the state or its supreme ruler as the highest institution. As the highest authority in a society established upon the principle of duty, the state was also in charge of education in general (ibid., 4).

To substantiate his view of the Confucian essence of Chinese culture, Jiang also devised a corresponding narrative of the Chinese history of ideas. In his vision of Chinese intellectual evolution, the Confucian school was portrayed as one of three contesting schools in the seminal period of Chinese philosophy, the pre-Qin period (before 221 BCE), which Jiang chose to designate as "the creative period" (ibid., 5). Thus, he set what he called the "Politico-ethical school" of Confucianism against the "Naturalistic school" of Daoism, which advanced a social philosophy based on "radical individualism" and

6 What is referred to as "cultural relativism" ought to be disambiguated from forms of cultural syncretism, which recognized Chinese subjectivity as historically parallel to that of other cultures and traditional ideas associated with Chinese identity and as equally essential to China's future as the advancements of Western materialist culture. In contrast to these harmonistic visions of Chinese modernity - as either positively or negatively assumed, for example, in the early thought of Zhang Shizhao 章士釗 (1881-1973), Du Yaquan 杜亞泉 (1873-1933), Liang Shuming 梁漱溟 (1893-1988), and Zhang Shenfu 張申府 (1893-1986) - cultural relativism was a form of constructive evolutionism set within the context of early ethnology and anthropology. As a current it gained momentum at Columbia in the 1920s, while in China it took more concrete shape in the early 1930s (see Li Guannan 2012). Strikingly, in the late 1910s, before Dewey visited China, his philosophy already contained inklings of awareness about cultural relativity, which raises an interesting question about the role of his Chinese doctoral students and his stay in China in the development of his later thought and its impacts at Columbia University. 
"anti-institutionalism" (ibid., 10). Jiang also listed the "Humanitarian school" of Mohism as a sort of middle current. Jiang simply evaluated the nature of other periods in the history of Chinese ideas based on their accord or discord with the Confucian politico-ethical line of thought. Unlike Hu Shi, who invested all his hopes in the logical thought of late Mohism (see Vrhovski 2020, 513-5), describing it as the repository of proto-pragmatist philosophy in China (Hu 1919, 8-9), Jiang saw the rudiments of pragmatist thought in Confucius, who was "a thoroughly practical man" (Jiang 1918a, 8).

In the spirit of contemporary Chinese modernist denunciations of Confucian tradition, Jiang passionately advocated the view that this politico-ethical school of Chinese philosophy was also the cause of the very problems responsible for China's lack of modernity. In Jiang's opinion, the notion of life and the social system given rise by Confucianism were also responsible for the vital problems of Chinese education, which were thus entirely socio-political in nature (ibid., 36). Similarly, according to Jiang, the nature of this prevalent school of ideas in Chinese society was also the main cause behind the lack of modern scientific thought in China. ${ }^{7}$ This view led Jiang to conclude that since the main ailments of Chinese society and education were politico-ethical in nature then so too must be a part of their modern remedies. The other part of the solution included introducing perspectives other than political and ethical ones as well as extensively introducing the scientific method of inquiry into school curricula. Since "education is the method of life and thought", reforming the Chinese system of education entailed a necessary "change of national life" (ibid., 147). Instead of moral collectivism, emancipated Chinese life ought to be derived from individualism based on rational morality (ibid., 148). But the moral problem of Chinese life ought not to be resolved overnight, for while rationality is universal, the collective or individual experience is not. In the "moral transition" of Chinese subjectivity envisaged by Jiang, a pivotal role was to be played by comparative ethics, which would be able to bridge the disparate strains of Chinese and global experience. Furthermore, the key role of experience in transforming "Chinese life" also implied the vital importance of improving its social conditions. ${ }^{8}$ Finally, the new notion of life in China also ought to be informed by modern natural science, in particular the "theory of organic evolution".

In summary, Jiang attributed China's lack of modern science to the absence of "a systematic approach towards reason" in Confucianism, its propagation of a "unitary ideal instead of particular" (Jiang 1918, 77), its "aphorical" (aphorismic) approach towards knowledge (ibid., 72), and the exclusive preference for practical philosophy (ethics and political philosophy) in Chinese society (ibid., 71).

8 Jiang claimed that Chinese philosophy essentially lacked such a "sociological definition of rational morals" (Jiang 1918, 148). Regarding the relationship between social conditions and moral change, Jiang remarked: "The change in moral ideas and method is generally brought about, either consciously or unconsciously, by the change of social forces. Therefore, a reconstruction of moral ideals is not only to be based upon the rational power of man, but also the social conditions in which he lives" (ibid., 148-9).

9 "One of the most important factors by which modern science has influenced education is the theory of organic evolution - that is to say, life grows from simple to complex. The process of evolution brings about variations; and through the struggle for existence and natural selection, the fittest survives. From this theory, the problem of life and environment, nature and nurture, or heredity and education, extends to the field of education. Evolution does not, however, mean progress. For progress implies the element of the conscious effort of man. Survival of the fittest does not necessarily mean survival of the most desirable according to human purposes. Education implies the conscious effort of man to create situations in such a way that they would favor the growth and survival of the most desirable in reference to purpose or purposes." (ibid., 185) 
In the conclusion of his dissertation, Jiang also proposed a list of concrete solutions for China's inherited problems. Not surprisingly, all solutions were derived from the pragmatist thought found in Dewey's works. First, Jiang suggested that the Chinese duty-centred notion of life could be enriched by the "Ancient Greek" (i.e., Aristotelian) view on life, in which the central place is occupied by the idea of happiness itself. ${ }^{10}$ While, as Jiang was strongly convinced, in Confucius' philosophy the right purpose of happiness was realization of social duty, in Aristotle's philosophy its ultimate purpose was "rational power" (ibid., 155). Second, according to Jiang, Chinese life should also be enriched through intellectualized morals as an alternative to the traditional normative notion of "moralized intellect" (ibid., 156). Third, Chinese life ought to be also enriched through Western notions of individualism and personal freedom. Jiang pointed out that the latter ought to be introduced to China through Roman law to substitute the traditional code of "propriety" ( $l i$ 禮) and the lack of the idea of freedom in Chinese traditional thought (ibid., 159); the legalist concept of law ( $f a$ 法) was an institution subjugated to the will of the sovereign. ${ }^{11}$ In combination with the classical idea of freedom, Western individualism was thus to set free the Chinese individual, who in traditional society was "sacrificed for maintaining social order" (ibid., 160). ${ }^{12}$ Third, while in Jiang's vision Confucianism was to be replaced with "Hellenism", ${ }^{13}$ old Chinese religions were to be replaced or at least supplemented by the "Christian idea of God" and the principles of Christian ethics (ibid., 164-7). ${ }^{14}$ Finally, Jiang claimed that "the future of China depends upon, besides other things, patriotism combined with modern science" (ibid., 167). All these ideals and objectives were to be achieved by means of the "science and art of education". As the main means of transmitting human experience and knowledge and as the principal means of enriching life, Jiang's pragmatist concept of education was also a means of social progress, training citizenship and leadership, promoting individual development, and spreading culture (ibid., 184).

10 Jiang adopted this definition of happiness from Aristotle and Dewey. In Dewey's philosophy, ultimate happiness is defined as a state of psychological/mental transcendence of physical sensations and the material conditions of one's life: "an abiding consequence or result, which is not destroyed even by presence of pains" (ibid., 154).

11 He enunciated that "the new Chinese is an individual and a citizen instead of a particle of the family. New freedom is fighting against the principles of propriety, and new citizenship against the family membership" (ibid., 178).

12 Jiang posited that something similar was attempted by the pre-Qin school of Daoism, or "the radical individual school", which "did not succeed in setting him free by attacking the social system of ancient China" (ibid., 160).

13 In addition to the above-described idea of life, the notion of Hellenism that Jiang spoke about also included the aesthetical conception of humans' bodily "perfectness" and the Hellenic "sense of beauty" (ibid., 156-7).

14 Specifically, Jiang asserted that "the future of Chinese civilization will be the coexistence of Christian-Confucian-Hellenic, Mohammedan-Confucian-Hellenic, and Buddhist-Confucian-Hellenic. The great old unifying forces are Confucianism, and the great new unifying forces in China will be Hellenism" (ibid., 167). 


\section{The Dawning of New Life: Jiang's Philosophy of Life in the Context of the May Fourth Movement, 1919}

The main reason I deemed it worthwhile to elaborate at length on the content of Jiang's dissertation is that, in the years following its defence, his lectures and publications in China were more or less recapitulations or minor extensions of the views presented in his dissertation. Following his return to China in 1917, in more than fifty articles and transcribed lectures published in 1918-19, Jiang expounded mainly his notions of a "new view on life" (xin rensheng guan 新人生觀), a new type of education, individualism, and personal freedom..$^{15}$ Jiang's propagation of pragmatist notions of life and education was significantly amplified in a series of newly founded journals devoted exclusively to pedagogy, one of which, New Education (Xin jiaoyu 新教育), he even cofounded. Following the appointment of $\mathrm{Hu}$ Shi as professor of philosophy at Peking University, pragmatism started gaining momentum in the Chinese intellectual world. In the year of the May Fourth Movement, 1919, Jiang was appointed professor of pedagogy at Peking University. Finally, the presence of pragmatism at the university reached its peak with the arrival of Hu's and Jiang's mentor, John Dewey. ${ }^{16}$

What is of special interest to us, however, is Jiang's notion of a "view on life", in particular in the context of the developments surrounding the May Fourth events. Understanding Jiang's advancement of the above-described theory at this time is even more important considering that expressions like rensheng guan and ziyou 自由 (freedom) had become key concepts associated with the movement. In fact, a superficial survey of writings by the movement's leading intellectuals reveals that, apart from socialist vocabulary and generic terms such as reform (gaizao 改造), by 1919, the term new view on life had become one of the key expressions synonymous with the universal reformation of Chinese society urged for by the movement. As I shall briefly indicate below, it appears that the term was, moreover, in general use among intellectuals of all ideological denominations. This became apparent in a public discussion that developed shortly after the May Fourth events. The debate, which revolved around the problem of suicide among Chinese youth, was provoked by the suicide of Peking University student Lin Deyang 林 德揚 in mid-November 1919. Having been the first such incident at the university since the May Fourth events, Lin's suicide prompted an intense debate between the movement's leaders at the university, including Cai Yuanpei 蔡元培 (1868-1940), Luo Jialun 羅家倫 (1897-1969), Chen Duxiu 陳獨秀 (1879-1942), and Jiang. The public discussion was also joined by other prominent intellectuals such as Dewey and Dharma Master Taixu 太虛法師 (Lü Peilin 吕沛林, 1890-1947). ${ }^{17}$ Most importantly, to present their own views on students'

15 E.g., “Education after the European War” (“Ouzhan hou zhi jiaoyu” 歐戰後之教育, 1918), “Education and Vocation" (“Jiaoyu yu zhiye" 教育與職業, 1918), “Society-Evolving Character Education" (“Jinhua shehui de renge jiaoyu”進化社會的人格教育, 1918), “The Relationship of the Value of the Individual to Education" ("Geren zhi jiazhi yu jiaoyu zhi guanxi” 個人之價值與教育之關係, 1918), “Dewey's Ethics” (“Duwei zhi lunlixue” 杜威之倫理學, 1919), “Students' Autonomy” ("Xuesheng zizhi” 學生自治, 1919), “Individuality and Individualism” (“Gexing zhuyi yu geren zhuyi” 個性主 義與個人主義, 1919).

16 On Dewey and China, see, e.g., (in the English language) Dewey 1973; Wang 2007; Wang 2019.

17 On the incident and the general discourse on suicide in China in this period, see, e.g., Liu 2008; Wang 2018; Zhang 2017, 142-7; and Lu 2008 (MA thesis). On the role of Dharma Master Tai Xu in the modernization of Chinese philosophy and religion, see Dessein, 2020. 
giving up on life or self-sacrificing themselves, all these important figures of the May Fourth Movement had to state their own views on life. Through their apophatic expositions of the value and social or psychological evolution of life, these scholars often revealed aspects of their thought that had not been adequately enunciated in their positive historical narratives.

For Jiang, this discussion came as an important opportunity to restate his philosophy of "new life", which he had been disseminating for the past two years. Moreover, the student incident of November 1919 fell exactly into the context of his lectures and writings in the months following the May Fourth events and prior to Lin's suicide. As mentioned above, in the intellectual ferment of the May Fourth Movement, rensheng guan became one of the key notions associated with the general psychological and intellectual change advocated by the movement. More specifically, it was one of the synonyms for its ultimate objective. Although, at this point, we are unable to establish the exact relationship between pragmatism and its terminology on one side and the ideational basis and terminology of the movement on the other, it can be claimed with some certainty that Jiang's propagation of a "new view on life" predated the sudden emergence of the term in the year of the May Fourth events. On the other hand, the May Fourth events also caused Jiang to write more extensively on the "new view on life", the attitude required for the transformation or change (gaibian 改變) of Chinese life, and related notions (e.g., Jiang 1919e, 1919f). Thus, in the article "Changing the Attitude towards Life" ("Gaibian rensheng de taidu” 改變人生的態度), in addition to reiterating the views formulated in his dissertation, Jiang also pointed out that one's attitude towards life needs to undergo the following transformations: from a narrow to a comprehensive, and from a simple to a complex view on life; from family life to social life; from solitary life to communal life; from emulation to creativeness; from obedience to the ancient doctrines to free thinking; and so forth (Jiang 1919e, 4). ${ }^{18}$ Jiang listed the following methods for reforming one's life: "repudiating old customs and ideas; studying Western literature, philosophy, science and art; and considering oneself as an individual brimming with life" (ibid.). Jiang also composed an article on "The Tolstoian View on Life" ("Tuoersitai rensheng guan" 托爾斯泰人生觀), which he, rather strikingly, considered to be in some ways exemplary (see 1919f). ${ }^{19}$ On the other hand, far less surprising was Jiang's appreciation of Tolstoy's combining individualism with altruism.

In September and October 1919, Jiang carried out a lecture tour from Peking to Hangzhou, speaking on the above-mentioned topics (Jiang 1919g, 113). Among other things, in his lectures he discussed the "psychological disposition of the youth" with respect

18 In an endnote Jiang also indicated that the term life used in his article encompasses the meanings “individual life" (rensheng 人生), “life" (shenghuo 生活), and “the life of humanity" (renlei de shenghuo 人類的生活).

19 In certain respects, Tolstoy's view on life as described in Jiang 1919 f differed significantly from the view expounded in Jiang's dissertation. Jiang enumerated five major postulates of the "Tolstoian view on life”: “(1) There was life (shenghuo 生活) before one's life (rensheng 人生), and there will be life after one's death; human life (rensheng 人生) is imperishable. (2) This life (xianshi 現世) represents only a stage of life as a whole. (3) This life contains two different aspects: (a) rational life and (b) a physical and brutal form of life. Rational life continues what was before birth and enlightens what follows after death. It is infinite... (4) Rational life promotes universal love. It is a life of service, forgetting oneself. It is mutualistic and unafraid of death. (5) Brutal life is selfish, conflicting, murderous, and terrified of death." (Jiang 1919f, 6) 
to the governmental repercussions against student protesters in June 1919. In the article "The Psychological Disposition of the Youth after Student Protests and the Optimal Method of Guidance" (“Xuechao hou qingnian xinli de taidu ji lidao fangfa” 學潮後青 年心理的態度及利導方法), which he subsequently published in the journal New Education, Jiang took up his pen in defence of the students who took part in the May Fourth Movement, endeavouring to explain the psychological state of mind to those in charge of China's institutes of education. Jiang emphasized that after the May Fourth events, Chinese youth embarked upon the path of a "revolution of the heart" (xin de geming 心的革命), along which they encountered various psychological challenges related to the reinvention and reestablishment of their selves. According to Jiang, this process included three main elements: a critical revaluation of everything (identity, customs, values, etc.), autonomous thought and expression (ziji xiang ziji shuo 自己想自己說, “thinking and speaking for oneself”), and seeking a new view on life (xin rensheng guan; ibid., 113-15). Most noteworthy, in the subsequent parts of his essay Jiang indicated that such a radical process of reinventing one's life-views also entails challenges and pressures, which emanate from the destructive side of psychological rebirth and the restraining mechanisms of the traditional establishment and political authority (cf. ibid., 115). Correspondingly, Jiang recommended those in charge of Chinese universities support China's social transformation by means of the following mechanisms: encouraging students' autonomy, giving students the chance to attain freedom of thought, assisting students in their studies of social problems, and helping them to attain a rich life (ibid., 116-17). These and other solutions proposed by Jiang were all, more or less, consistent with the views explicated in his dissertation. ${ }^{20}$ However, now, when Jiang was witnessing the reality of social transformation and his notion of a "new view on life" was challenged by the concrete psychological complexities of intellectual reform, much darker visions started to emerge on the horizon of Chinese history. Thus, when in October 1919 Jiang was discussing student protests with a few "foreign colleagues" in Shanghai, asserting that their psychological disposition includes general scepticism, intellectual freedom, and a change of lifeviews (gaibian rensheng guan 改變人生觀), one interlocutor pointed out that the current intellectual transformations in Chinese youth comprise "a very dangerous undertaking, because of which, I am afraid, in the future many young people are going to commit suicide" (Jiang 1919h, 349). Jiang allegedly (ibid.) received the same warning from Dewey, whom he met later in the same year. One day after his discussion with the latter, Lin Deyang committed suicide, an incident which reverberated through Chinese intellectual circles. The incident was met with an intense response, not only because it was the first such incident at the prestigious Peking University, but more so because of its apparent symbolical value and overall "intellectual context", since it took place at the height of the May Fourth Movement's revolutionary fervour, which promulgated the beginning of a new era in Chinese intellectual history. In the penultimate section of this paper, I will briefly summarize the discussion on suicide that followed the aforementioned incident of November 1919, focusing on Jiang's contribution.

20 E.g., Jiang particularly stressed that professors at Chinese universities ought to encourage and assist students in their studies of ethical problems, foster their interest in natural sciences, and encourage playing musical instruments and performing theatre (Jiang 1919g, 117). 


\section{Against Self-Resignation: Jiang's Contribution to the 1919 Polemics on Suicide}

One of the earliest Chinese debates on suicide started with a proclamation made by the university president, Cai Yuanpei, in the school's daily newspaper. It was followed almost immediately afterwards by a series of articles written by a few leading Chinese intellectuals. Among the first was a response from Luo Jialun 羅家倫 (Zhixi 志希, 1897-1969), one of the founders of the reformist New Tide (Xinchao 新潮) journal and a leading member of the May Fourth intellectual elite. In his article "A Suicide of a Young Person or Society's Murder of a Young Person" ("Shi qingnian zisha haishi shehui sha qingnian” 是青年自殺還是社會殺青年), Luo described the late student Lin as an exemplary personality and a genuine patriot whose self-sacrifice was not entirely without meaning (Luo 1919a, 347). ${ }^{21}$ For Luo, the most natural and logical explanation for Lin's sacrifice resided in his existential and psychological discord with the social injustice and intellectual backwardness of Chinese society. However, in his essay Luo inquired further into the reasons students like Lin would consider suicide as the only way of affecting the order under heaven (tianxia 天下). He claimed that in contrast to foreign students who "commit suicide mostly because of problems [related to] love or failing an exam", the existential anxiety and discord of Chinese students stemmed from their "lack of artistic life" (meishu de shenghuo 美術的生活) and their "lack of social life" (shejiao de shenghuo 社交的生活), while the main cause of students' suicides during the May Fourth events was the "negative countereffect of the change of life-views (rensheng guan)" (ibid.). Luo also added that "after the 'May Fourth', great enlightenment will occur in our youth's view on life, by which it will overthrow the idols of old and which will give rise to a mentality of being sceptical of everything" (ibid.). Finally, Luo also pointed out that he was not against the suicide of world-weary people, nor did he consider it to be an immoral act. ${ }^{22}$ Moreover, he claimed that suicide can be the most honourable and natural thing to do after one has run out of all means and energy for changing this “detestable world" (keyan de shi 可厭的世). Following the same rationale, Luo defined the reformist sentiment of "world-weariness" (yanshi 厭世) as an inherent anxiety or discontent with the onto-moral order of this world (society), which is a sign of one's superior moral fibre. In contrast with the Confucian idea that, in times of disorder, the sage ought to leave this world and go into seclusion, ${ }^{23}$ Luo's modern sage embodied

21 Luo's article was originally published in Chenbao 晨報 and reprinted in Vol. 2, No. 2, of the journal Xinchao 新潮, where an entire section was dedicated to a discussion of suicide.

22 In one of his earlier papers Luo (1919b) pointed out the following: "This generation of our youth must, above all, go out and struggle, and engage actively in reformation of the current circumstances, transforming the detestable world into a non-detestable one. If in their struggle their strength wears out and they run out of resourcefulness and viable plans, so that they are incapable of undertaking the slightest bit of action and receive not even an iota of support from this world, then they will [be forced to] commit suicide... This kind of suicide is the most honourable thing in this world.... If in this world there were no people willing to commit suicide, we would not be able to get anything in order." (Luo 1919b, 684)

23 E.g., Confucius' Analects, "Tai Bo": "Let yourself be seen when the Way prevails in the Empire, but keep out of sight when it does not" (Lau 1992, 73; “Tianxia you dao ze jian, wu dao ze yin” 天下有道 則自，無道則隱). See also Huang 2019, 35. 
in the revolutionary youth was supposed to go one step further and dauntlessly sacrifice his or her life for the benefit of the community. In this sense, life in seclusion offered no alternative mode of existence that would alleviate the psychological pressure from the reformist's anxious soul. Moreover, Luo's notion of modernist reformation presupposed a radically mundane hero, who recognizes the ontological imperative of change and understands that the transcendent world can offer no consolation whatsoever. Hence, the only locus of "life" was exclusively here and now, while its quality was to be measured exclusively after the material and psychological state of the youngest among the enlightened members of the community. Most importantly, this view also presupposed a quasi-Mencian notion of innocence, ${ }^{24}$ which, in combination with the moral purity of the reformist, gave his or her act of her self-sacrifice its tremendous and more than symbolic power. Thus, when Luo concluded that "Lin did not commit suicide but was murdered by society" (Luo 1919a, 348), this also implied that the act of self-resignation still took part within a world order in which a universal moral tissue formed a unity with the physical, ontological aspect of the world, for the cause and ends of suicide were considered to be essentially moral and its repercussions, fundamentally cosmological in nature. What is even more important for our debate, Luo's view on suicide implied that the positive notion of "the view on life" was essentially also tantamount to a spontaneous externalization of human nature ${ }^{25}$ in its still untarnished and morally purest form. Because, concurrently, his idea of rensheng guan also encompassed the objectivist segment of awakening to the true nature of the world, his objectivist idea of weariness these sentiments were considered the ultimate standard of the verity and rightfulness of the general state of society - as the underlying cause of suicide in youth was still rather close to the Confucian concept of “anxiety” (buian 不安) of the people as a critical gauge for measuring the state's accordance with the course of heaven (and never the state of the

24 It could be claimed that a similar notion of innocence was assumed via the Confucian idea of duty related to one's social position and role in society (as in “jun jun, chen chen, fu fu, zi zi” 君君, 臣 臣，夫夫，字字 [A ruler is a ruler, a minister a minister, a husband a husband and a son a son], Lunyu 論語, “Yan Yuan”顔淵, 12.11). In my opinion, the Mencian notion of the fundamental goodness of human nature and his advocacy of the right of the people to reproach an inhumane ruler are consistent with the Confucian notion of responsibility towards others as one of the highest standards of human conduct, which forms an essential part of the Confucian concepts of ren 仁 (humaneness) and $y i$ 義 (appropriateness). The innocence or purity achieved through complete fulfilment of one's duties makes one susceptible to disharmony or harmony with the way of the heaven, which consists in the kingly way (wangdao 王道) of governance and its opposite, the hegemonic way (badao 霸道) of governance ( $z h i$ 治; see Huang 2020, etc.). The same innocence could be recognized in the Neo-Confucian discourse on the path leading to the perfection of one's "innate moral nature and life" (daode xingming 道德性命), which, in a certain sense, bridges the spheres of “inner sageliness" (nei sheng 内聖) and “outer kingliness" (wai wang 外王; cf. Lee 2020, 28-33). Similarly, the nexus between inner cultivation and the external assertion of the right principle depends heavily on the notion of "original knowledge" (liangzhi 良知) and the possibility of its extension to society (i.e., $\min$ 民). Although this was not explicitly expressed in the classical Confucian discourse, I believe that, as noted in the summary of Jiang's dissertation, this notion of duty was inadvertently maintained by some of the modern Chinese intellectuals under discussion. I further believe that a certain concept of innocence is the main precondition for disobedience (buzhong 不忠, “disloyalty") and revolt, especially when it comes to social orders founded on onto-moral conceptions of reality. However, without further analysis and additional evidence the above claims remain pure speculations.

25 Here, I am not referring to the traditional Chinese concept of renxing 人性. 
latter as the external objective cause) and one of the possible reasons for "revolution". ${ }^{26}$ All these dimensions of the notion of rensheng guan, which crystallized in Luo's May Fourth expositions of the problem of suicide, are also of tremendous importance for understanding Jiang's notions of life and death.

Jiang Menglin's notion of life also became best apparent in his views on suicide. If, in the terms of Durkheim's theory of suicide, Luo's understanding of Lin's suicide was predominantly altruistic, Jiang's notion of suicide could be regarded as a combination of egoistic and anomic suicide. ${ }^{27}$ Although Jiang agreed with Luo's assumption that the main solutions to the suicide problem resided in enabling the youth to live artistic lives, encouraging social interaction with their peers, and helping them to establish new views on life, he categorically opposed Luo's views on the nature and acceptability of suicide as a final means of social reformation (Jiang 1919h, 349). As noted in the above summary of Jiang's dissertation, he understood the transition between traditional and modern Chinese society to be a process of emancipating the individual, in which duty as the sole purpose of life ought to be replaced with happiness in the first place and the intellectual and material progress of society in the second place. Thus, although the goal of liberation was to overturn the traditional relationship between the individual and the collective, the evolutionary categorical imperative of undertaking such change was based on an entirely different conception of morals and innocence. A significant disparity between the idea of the individual in Luo's and Jiang's views on life and suicide resided in the latter's strong propensity towards American individualism, whereas in Luo's case the liberation of the individual was still imagined to be in direct service to communal progress and awakening. Thus, the consequences of disharmony between the state of society and the psychological state of the individual in Luo's view on life and the consequences of self-sacrifice were entirely different from those conceived in Jiang's pragmatist individualism. Jiang's turn from duty-based innocence to the duty of personal cultivation meant that the happiness and enlightenment of the individual, although closely bound to the intellectual progress of society as a whole, were positioned above that of one's community. While recognizing the urgency of attaining personal and social liberty was a direct consequence of human intellectual advancement, enlightenment was primarily required of the individual. An important addition to Jiang's view on life was also related to his adoption of a "vitalist" notion of life, which established its sanctity within the context of the theory of the natural evolution of life. As mentioned earlier, this caused pragmatists like Dewey to view survival as the principal driving force behind all human endeavours and the capacity to adapt to the changing circumstances of the world as the highest means of guaranteeing this survival. A major corollary to that was that one's view on life ought to be liberated from "transcendental morality", while the highest form of morality was to become immanent, situational, and more closely associated with the concrete causalities of the physical world that our survival depends on. Ethics, on the other hand, became associated with the general principles derived from humans' knowledge of the enrichment and preservation of life.

26 The term revolution is a conceptual approximation of the traditional Chinese term geming 革命, which can be neutrally translated as "changing the mandate of heaven", etc.

27 See Durkheim 2002, 175-200. Durkheim described egoistic suicide as a result of excessive individuation, and altruistic suicide as a result of insufficient individuation (ibid., 175). 
Consequently, in contrast to the later Chinese version of vitalism (cf. Bodenhorn 2002), as a pragmatic vitalist, Jiang's main infatuation was with life as an individual entity, which made its destruction the highest form of transgression. One of the most defining features of Jiang's idea of sanctity of life was that he believed it to be an essential characteristic of Christian morality. Akin to his idea of enlightenment, Jiang regarded happiness and survival as an individual's own responsibility, and therefore refuted Luo's notion that Lin's suicide was a crime committed by society. Moreover, Jiang hinted that this very view was symptomatic of the backwardness of traditional Chinese socio-political thinking. Although Jiang did concur that the society to which Luo had referred to was indeed “abominable" (elie 惡劣), he added that "society cannot improve itself, but needs us to do so. If we commit suicide before society has been changed for the better, will there ever come a day when this society will be improved?" (Jiang 1919h, 349). In this way, transgression against the sanctity of one's own life was ultimately also tantamount to a crime against society. Moreover, in Jiang's view suicide was nothing but a portrayal of not only one's personal weakness but also the weakness of spirit inherent in the traditional Chinese mentality (ibid.). Although Lin's suicide was "equal to killing a respected member of society", the guilt for this murder must be attributed to Lin himself. Most importantly, Jiang regarded Lin's suicide as a resignation that took place in the context of the Chinese youth's collective struggle for a new view on life, which was thus the primary objective of the May Fourth Movement: "a new view on life cannot be created in a moment. In the interim, there will constantly occur numerous difficulties and hopeless causes... Difficulties are the path to success. In the endeavour to break new ground, one will always stumble upon thorns" (ibid., 350). And at the end of this path Jiang envisaged a new life, which cannot be attained in a moment, but through ceaseless everyday effort: "it must be attained by means of experimental attitude" (ibid.). It thus follows that, in Jiang's view on life, the anxiety encountered by the individual undergoing mental transformation is a universal ingredient of the struggle for the preservation and progression of life as well as a psychological factor confined to the individual's experience. As such, anxiety is a key component of personal growth shared by all members of the species and not primarily an internalization of the external onto-moral order as in the case of Luo's view on suicide, while one of the pivotal tasks of education is to alleviate such psychological pressure emanating from the deconstruction and reconstruction of one's view on life. Akin to Luo's theory, Jiang's notion of anxiety also represents the cognitive dissonance between the recognized true nature of the universe (imperative in a temporal perspective) and the current state-of-affairs in human society - or one's cognitive consonance with the universe - the main difference between them being the moral dimensions of the materialization of anxiety in the act of "altruistic suicide". Jiang regarded suicide as unacceptable because the main goal of transforming the "view on life" resided in the establishment of "new life" primarily at the individual level, and only secondarily at the level of human society as a whole. We could also call this a form of non-transcendental individualist vitalism, in contrast to the standpoint that the idea of collective life transcends individual existence. However, at the same time Jiang retained a certain degree of moralism or duty, which was now reduced to the intimate relationship between the struggling individual on one side and the transcendental idea of perpetual life (totality of life or bios) on the other. Arguably, 
this could be regarded as the main point of contention between the collectivist and individualistic notions of "revolution" in the framework of the May Fourth Movement, while in both cases cognitive consonance with the underlying pattern of reality was regarded as a moral and existential precondition for the revolutionary prerogative.

Jiang's response was followed by Chen Duxiu's lengthy analysis of suicide from the perspective of social problematics and other contributions on the topic. ${ }^{28}$ Although Jiang did not contribute any other papers to the debate, he superficially touched upon the topic in his lectures and publications on youth and education, which he delivered and published together with $\mathrm{Hu}$ Shi around the first anniversary of the May Fourth Movement. ${ }^{29}$ In the year immediately after the May Fourth events, the focus of Jiang's writing shifted to general problems of education, its relationship with politics (partisanship), and youth-related questions, while his attention seemed to have moved slightly away from his philosophy of life as one of the central backgrounds of his discussion. He also gradually adopted new terminology denoting the process and the final destination of the wave of Chinese modernization that started in $1919 .{ }^{30}$

\section{Concluding Remarks}

The above analysis has shown that the socially and morally most significant features of Jiang's notions of a new "view on life" and "life" were revealed in their apophasis (negative definition), that is, in the discussion on suicide that took place in late 1919. As demonstrated in the initial part of this study, the positive description of Jiang's philosophy of life was derived theoretically from the version of pragmatist philosophy in vogue at Columbia University at the time of Jiang's doctoral studies.

Since the main aim of this study has been to give a more concise picture of Jiang Menglin's notion of rensheng guan and its position in Jiang's pragmatist philosophy, this shall be given in the following few points recapitulating and supplementing the findings made in the study:

(1) In the period under observation, Jiang's philosophy and notion of life were deeply rooted in pragmatist ontology. In his dissertation he posited that the main developmental problem of Chinese society resided in its Confucian foundations, which disrupted the optimal relationship between the individual and society, which would enable human life to prosper at the same level as in the West. Consequently, to ameliorate the deteriorating consequences of Chinese tradition, he proposed a change in the "view on life" and

28 Chen's article “Theory of Suicide” (“Zisha lun”自殺論), which was published in Xin qingnian 新青 年 (La Jeunesse) and closely resembled Durkheim's analytical approach in terms of style, systematically presented the social causes of suicide amongst youth. Chen's profoundly socialistic theory of suicide was opposed by one of the leading members of the contemporary Chinese Buddhist community, Dharma Master Taixu (Taixu fashi 太虛法師). Later in December a discussion of suicide also appeared in the magazine The New Society (Xin shehui 新社會, 11 December 1919).

29 E.g. Hu and Jiang 1920, etc.

30 By the mid-1920s, for example, Jiang's terminology became more "revolutionary" in the sense that he more often resorted to terms such as revolution, age of revolution, and so on to describe the reformation of society (see Jiang 1927). Because at the same time, more "humanistic" terms such as view on life, Hellenistic culture, etc. started to appear less often in Jiang's texts and lectures, we could understand this terminological peculiarity as distantly reflective of Jiang's intellectual development. 
ultimately also the establishment of "new life", which would be based on the Hellenistic ideal of human life, Roman legal individualism, natural science, and relativistic (i.e., universalist) ethics.

(2) Because of pragmatism's inherent bent towards certain segments of contemporary biological science (evolutionary theory and its notion of biological life) and its concurrent reestablishment of a kind of ethical relativism based on the idea of individual growth and freedom, Jiang's notion of life, on the one hand, antagonized the traditional (Confucian) idea of individual life and, on the other hand, contained an internal schism between social individualism and evolutionary collectivism manifested in the institute of public education. The issues associated with this onto-moral gap manifested themselves in the apparent lack of in-depth analysis of the psychological mechanism of the change of the "view of life" so optimistically propagated in Jiang's seminal work. Hence, while Jiang was mainly concerned with the ailment-medicine approach towards the problem of Chinese society, drawing the idea of life from the contemporary pragmatist discourse, he almost completely neglected the negative aspects of such a transformation in the first place.

(3) While Jiang adhered to the Aristotelian idea that "happiness" instead of "duty" ought to be the main goal of one's life, he entirely neglected the antithetical concepts of discord and anxiety, which would turn out to be integral to extending his theory into more practical issues related to social reformation and its educational aspects. These inadequacies of Jiang's original exposition of a "view on life" became more apparent in the debate on suicide in November 1919. The contrast between Luo Jialun and Jiang, the first two participants in the debate, revealed a fundamental turn in morality and the "vitalist" and "social" transcendentalism assumed in different cases of rensheng guan as philosophical worldviews, and hence also conceptions of rensheng or "human life". As pointed out in the penultimate chapter of this study, Jiang's divorce from traditional holistic morals, which was importantly attested in his notion of human life, thus became the essential ingredient of his individualist vitalism, in which society was exempt from one's primal internal relationship to the transcendental ideal of life as a whole and hence de-essentialized. The former idea of complementarity between all modes and forms of existence, endowed with the onto-moral ideal of all-pervading (internal and external, etc.) harmony, was replaced with a primarily personalized relationship with the preservation and enrichment of life as the objectivized (through natural science) transcendental ideal. Although in Jiang's philosophy this position did not eliminate altruism as an important ethical value and pragmatic category, the latter was considered secondary in the case of phenomena such as the psychological, spiritual, or mental transformation underlying the "change of (views on) life". Hence, forms of anxiety and discontent sanctified in other segments of revolutionary discourse became disconnected from the old onto-moral tissue of the universe. As a consequence, one's suffering in the process of transformation could not result in society-changing mechanisms of guilt, shame, and collective spiritual experiences of self-sacrifice, but in a mere obstacle experienced in personal growth. However, even if it would appear as if this perspective managed to break away from one aspect of the "antiquated" Confucian ideology, in fact, it merely managed to obscure one aspect while immersing itself more deeply in its other aspect. 


\section{BIBLIOGRAPHY}

Bodenhorn, Terry (2002). “Chen Lifu's Vitalism: A Guomindang Vision of Modernity Circa 1934." In: Terry Bodenhorn (ed.), Defining Modernity: Guomindang Rhetorics of a New China, 1920-1970. Ann Arbor: Center for Chinese Studies, The University of Michigan, 91-123.

Chen, Duxiu 陳獨秀 (1919). “Zishalun: sixiang biandong yu qingnian zisha” 自殺論: 思想變動與青年自殺 [Theory of Suicide: Intellectual Change and Suicide in Youth]. Xin qingnian 新青年 7:2,1-13.

Dessein, Bart (2020). "The Heritage of Taixu." Asian Studies 8:3, 251-77.

Dewey, John (1909). Moral Principles in Education. Boston, New York: Houghton Mifflin Company.

Dewey, John (1910a). How We Think. Boston, New York: D. C. Heath \& Co. Publishers.

Dewey, John (1910b). The Influence of Darwin on Philosophy, and Other Essays on Contemporary Thought. New York: Henry Holt and Company.

Dewey, John (1916a). Democracy and Education. New York: Macmillan.

Dewey, John (1916b). Essays in Experimental Logic. Chicago: University of Chicago.

Dewey, John (1973). John Dewey: Lectures in China, 1919-1920. Translated and edited by Robert W. Clopton and Tsuin-Chen Ou. Honolulu: The University Press of Hawaii.

Durkheim, Émile (2002). Suicide: A Study in Sociology. Edited by Georg Simpson, translated by John A. Spaulding and Georg Simpson. London and New York: Routledge \& Keegan Paul.

Furth, Charlotte (2002). "Intellectual Change: From the Reform Movement to the May Fourth Movement, 1895-1920." In: Merle Goldman and Leo Ou-Fan Lee (eds.), An Intellectual History of Modern China. Cambridge, New York: Cambridge University Press.

Guo, Hua-qing 郭華清 (2000). “Jiayin shiqi Zhang Shizhao de zhexue sixiang - tiaohelun” 甲寅時期章士釗的 哲學思想 - 調和論 [Zhang Shizhao's Philosophical Thought in the Period of Jiayin (The Tiger) - The Theory of Harmony]. Supplement to the Journal of Sun Yatsen University (Social Science Edition) 20:3, 150-62.

Huang, Chun-chieh (2019). The Debate and Confluence between Confucianism and Buddhism in East Asia. Göttingen: V\&R Unipress.

Huang, Chun-chieh (2020). "Between Humane Governance and Hegemony: A Study of East Asian Confucian Discourse on Guan Zhong and Related Questions." International Communication of Chinese Culture 7:4, 411-43.

$\mathrm{Hu}$, Shi 胡適 (1919). Shiyan zhuyi 實驗主義 [Pragmatism]. Nanjing: Xueshu jiangyan hui.

Hu, Shi 胡適 and Jiang, Menglin 蔣夢麟 (1920). “Yi nian lai xuechao zhi huigu he xiwang: Women duiyu xuesheng de xiwang”一年來學潮之回顧和希望：我們對於學生的希望 [A Look Back and Hopes One Year after Student Protests: Our Hopes for the Students]. Xin jiaoyu 新教育 2:5, 89-94.

$\mathrm{Hu}$, Shih (1922). The Development of the Logical Method in Ancient China. Shanghai: The Oriental Book Company.

Jiang, Menglin [Monlin Chiang] (1918a). A Study in Chinese Principles of Education. Shanghai: Commercial Press, Ltd.

Jiang, Menglin 蔣夢麟 (1918b). “Ouzhan hou zhi jiaoyu” 歐戰後之教育 [Education after the European War]. Xin minde 新民德 3:2,10-12.

Jiang, Menglin 蔣萝麟 (1918c). “Jiaoyu yu zhiye” 教育與職業 [Education and Vocation]. Dongfang zazhi 東方雜志 15:12, 149-50.

Jiang, Menglin 蔣营麟 (1918d). “Jinhua shehui de renge jiaoyu”進化社會的人格教育 [Society-evolving Character Education]. Jiaoyu zazhi 教育雜志 10:6, 79-82.

Jiang, Menglin 蔣夢麟 (1918e). “Geren zhi jiazhi yu jiaoyu zhi guanxi” 個人之價值與教育之關係 [The Relationship of the Value of the Individual to Education]. Jiaoyu zazhi 教育雜志 10:4, 59-62.

Jiang, Menglin 蔣䓪麟 (1919a). “Xin jiu yu tiaohe” 新舊與調和 [The New and the Old and Their Mediation]. Jiefang yu gaizao 解放與改造 1:5, 76-9.

Jiang, Menglin 蔣萝麟 (1919b). “Duwei zhi lunlixue”杜威之倫理學 [Dewey’s Ethics]. Xin jiaoyu 新教育 1:3, $38-45$.

Jiang, Menglin 蔣萝麟 (1919c). “Xuesheng zizhi” 學生自治 [Students' Autonomy].Xin jiaoyu 新教育 2:2, 19-22.

Jiang, Menglin 蔣夢麟 (1919d). “Gexing zhuyi yu geren zhuyi”個性主義與個人主義 [Individuality and Individualism]. Jiaoyu zazhi 教育雜志 11:2, 27-29.

Jiang, Menglin 蔣夢麟 (1919e). “Gaibian rensheng de taidu” 改變人生的態度 [Changing the Attitude towards Life]. Xin jiaoyu 新教育 1:5, 1-4 [451-54]. 
Jiang, Menglin 蔣夢麟 (1919f). “Tuoersitai rensheng guan”托爾斯泰人生觀 [The Tolstoian View on Life]. Xin jiaoyu 新教育 2:1, 1-6.

Jiang, Menglin 蔣萝麟 (1919g). “Xuechao hou qingnian xinli de taidu ji lidao fangfa” 學潮後青年心理的態 度及利導方法 [Psychological Disposition of the Youth after Student Protests and the Optimal Method of Guidance]. Xin jiaoyu 新教育 2:2, 113-18.

Jiang, Menglin 蔣夢麟 (1919h). “Beida xuesheng Lin Deyang jun de zisha: jiaoyu shang shengsi guantou de da wenti” 北大學生林德揚君的自殺：教育上生死關頭的大問題 [Peking University Student Lin Deyang's Suicide: The Big Question of the Juncture between Life and Death in Education]. Xinchao 新潮 2:2, 349-50.

Jiang, Menglin 蔣夢麟 (1927). “Geming shidai zhi qingnian” 革命時代之青年 [The Youth in the Age of Revolution]. Qingbai 青白 1:1, 8-9.

Jiang, Menglin 蔣夢麟 (2004). Jiang Menglin zizhuan: Xichao yu xinchao 蔣夢麟自傳：西潮與新潮 [Jiang Menglin's Autobiography: Tides from the West and New Tides]. Beijing: Tuanjie chubanshe.

“Jiangxueshe huanying Luosu zhi yanci” 講學社歡迎羅素之演詞 [Welcome Speech for Russell at the Chinese Lecture Society]. Jiaoyu gongbao 教育公報 7:12, 23-24.

Lau, D. C. trans. (1992). The Analects. Hong Kong: The Chinese University Press.

Lee, Ming-huei (2020). “The Problem of 'Inner Sageliness and Outer Kingliness' Revisited: On the Controversy Raised by Yu Shiying's Work Zhu Xi's Historical World.” In: Jana S. Rošker (ed.), Modern and Contemporary Taiwanese Philosophy: Traditional Foundations and New Developments. Newcastle upon Tyne: Cambridge Scholars Publishing, 22-38.

Li, Guannan (2012). "Cultural Policy and Culture under the Guomindang." In: Arif Dirlik, Guanna Li, and Hsiao-pei Yen (eds.), Sociology and Anthropology in Twentieth-century China: Between Universalism and Indigenism. Hong Kong: The Chinese University Press, 109-37.

Liu, Changlin 劉長林 (2008). “Lin Deyang zisha de yiyi” 林德揚自殺的意義 [The Meaning of Lin Deyang's Suicide]. Wuhan ligong daxue xuebao (shehui kexue ban) 武漢理工大學學報 (社會科學版) 21:4, 574-78.

Lu, Kexia 魯克霞 (2008). “Minguo qianqi zisha wenti yanjiu zhi tanxi (1912-1930)” 民國前期自殺問題研究 之探析 [An Analysis of the Discourse on Suicide in the Early Republican Period (1912-1930)]. MA thesis. Hangzhou: Suzhou University.

Luo, Jialun 羅家倫 [Zhixi 志希] (1919a). “Shi qingnian zisha haishi shehui sha qingnian” 是青年自殺還是 社會殺青年 [A Suicide of a Young Person or the Society’s Murder of Youth]. Xinchao 新潮 2:2,346-48.

Luo, Jialun 羅家倫 [Zhixi 志希] (1919b). “Chushi'?”出世? [Withdrawing from the World]. Xinchao 新潮 $1: 4,682-84$.

Ma, Yong 馬勇 (1997). Jiang Menglin jiaoyu sixiang yanjiu 蔣萝麟教育思想研究 [A Study of Jiang Menglin’s Educational Thought]. Shenyang: Liaoning jiaoyu chubanshe.

Nelson, Eric S. (2020). "Zhang Junmai's Early Political Philosophy and the Paradoxes of Chinese Modernity." Asian Studies 8:1, 183-208.

Rošker, Jana S. (2021). "Chinese Philosophy of Life, Relational Ethics and the COVID-19 Pandemic." Asian Philosophy 31:1, 64-77.

Vrhovski, Jan (2020). "From Mohism to the School of Names, from Pragmatism to Materialist Dialectics: Chinese Interpretations of Gongsun Longzi as a Text and Source of Chinese Logic, 1919-1937." International Communication of Chinese Culture 7:4, 511-38.

Wang, Jessica Ching-Sze (2007). John Dewey in China: To Teach and to Learn. New York: State University of New York Press.

Wang, Lei (2019). John Dewey's Democratic Education and Its Influence on Pedagogy in China, 1917-1937. Wiesbaden: Springer VS.

Wang, Song 王頌 (2018). “Cong Taixu dui Chen Duxiu 'Zisha lun' de piping guankui qi rensheng zhexue” 從太 虛對陳獨秀《自殺論》批評管窥其人生哲學 [A Look on Taixu’s Philosophy of Life from the Perspective of His Critique of Chen Duxiu's “Theory of Suicide”]. Beida foxue zazhi 北大佛學雜志 1, 212-26.

Zhang, Junmai 张君朸 et al. (1997). Kexue yu renshengguan 科學與人生觀 [Science and the View on Life]. Jinan: Shandong renmin chubanshe.

Zhang, Xueqian 張學謙 (2017). “Tuise de 'chongbai': wusi moqi zhishi qingnian jiazhi xingxiang de fenqi yu chonggou” 褪色的“崇拜”: 五四末期知識青年價值形象的分歧與重構 [Fading “Worship”: The Divergences and Reconstructions of Images of Value in Intellectual Youth of the Late May Fourth Period]. Xiandai Zhongguo wenhua yu wenxue 現代中國文化與文學 23:4, 139-54. 